\title{
Q.
QNEEN'S
UNIVERSITY
BELFAST
}

Michael Field's Wordsworth

Murray, A. (2021). Michael Field's Wordsworth. Victorian Poetry, 58(4), 427-450.

https://doi.org/10.1353/vp.2020.0029

\author{
Published in: \\ Victorian Poetry
}

Document Version:

Peer reviewed version

Queen's University Belfast - Research Portal:

Link to publication record in Queen's University Belfast Research Portal

\begin{abstract}
General rights
Copyright for the publications made accessible via the Queen's University Belfast Research Portal is retained by the author(s) and / or other copyright owners and it is a condition of accessing these publications that users recognise and abide by the legal requirements associated with these rights.

Take down policy

The Research Portal is Queen's institutional repository that provides access to Queen's research output. Every effort has been made to ensure that content in the Research Portal does not infringe any person's rights, or applicable UK laws. If you discover content in the Research Portal that you believe breaches copyright or violates any law, please contact openaccess@qub.ac.uk.
\end{abstract}




\section{Michael Field's Wordsworth}

Alex Murray

In 1894 Edith Wingate Rinder's anthology Poems and Lyrics of Nature was published as part of the Canterbury Poets series edited by William Sharp. Rinder, now most often remembered as an English translator of Maeterlinck, muse of Sharp, and member of Patrick Geddes's Edinburgh circle, had collected verse by a wide-ranging and surprising group of contemporary poets; while many were recognised nature writers, such as Roden Noel, William Canton, Charles Armstrong Fox, and Norman Gale, the volume is more noteworthy for collecting the urbane, cosmopolitan poets of Decadence and Aestheticism, including lyrics by John Davidson, Lionel Johnson, John Gray, Richard Le Gallienne, Arthur Symons, Oscar Wilde, John Addington Symonds, Ernest Rhys, and W. B. Yeats. Just as, if not more, significant was the prominent place accorded to female writers in the anthology. As Rinder explained in her introduction, "[n]ot the least remarkable feature of the evolution of Victorian poetry is the high place occupied by women, from Mrs. Browning onwards; and by women, let me add, not the least noteworthy nature poetry of our time is written." ${ }^{\prime 1}$ The female Aesthetes and Decadents whose poetry featured in the anthology included Mathilde Blind, Edith Nesbit, Graham R. Tomson (Rosamund Marriott Watson), Alice Meynell, Katherine Tynan, and A. Mary F. Robinson. While Rinder had assembled a motley crew of poets, she claimed that they all shared an important context that shaped their nature lyrics in significant ways:

It is from Wordsworth that our later poets accepted the suggestion to throw away the note-book and to trust to the impression; he has taught us that it is better to record a true impression of a transient aspect or a commonplace detail keenly observed and emotionally recollected, than to describe categorically a whole landscape. It is in this sense that Wordsworth is called the father of modern poetry. He taught us to feel with 
nature as well as to observe her, and thus helped to free us from the lingering conventions of the academic school (Rinder, p.xxxvii).

Rinder's version of Wordsworth here is clearly inspired by Walter Pater's two essays (1874 and 1889) on the Lake poet, but her attempts to frame him as a nascent impressionist are somewhat questionable (since impressionism is predicated on trying to capture sensory experience), as is her suggestion that Wordsworth taught his reader to "feel" nature (philosophical reflection being a peculiar mode of feeling). ${ }^{2}$ Rinder's celebration of the post-Wordsworthian nature writing fell on hollow ears when Katharine Bradley and Edith Cooper (who wrote as Michael Field) received their copy of Rinder's anthology on June $1^{\text {st }}$. The two women were dissatisfied with the six Michael Field poems chosen by Rinder from the first edition of Underneath the Bough (1893), and in their journal Cooper declared that "we don't touch nature yet in a truly personal way". Those poems - "Winds To-day", "Noon", "O Wind", "Great Violets", "I will Sing”, and "Sunshine” are hardly uniform, yet there is a sense in them all of a disconnect between the speaker and the natural world. Take, for instance, "Noon" in which the speaker laments that "Of all that beauty by the light defined/None shares my vision! Sharply on my mind/ Presses the sorrow: fern and flower are blind" (Rinder, p. 98). The irreconcilable difference between speaker and nature is repeated in 'Great Violets" where a bee is "thwarted" by a flower in "early youth/ Shut still from desire" (Rinder, p. 101). In "Sunshine", the sun's significance is solely related to its role in providing Bacchus with the liquor necessary for his intoxication: "we can only be drunk with that/ Kindling the wine that brims the autumn vat!" (Rinder, p. 103). The lack of harmony with nature in these poems, and their reliance on stock pastoral motifs led Cooper to declare, on receipt of Rinder's anthology, that their poetry was "a little stiff before the world - not as yet warm and atmospheric as it should be". While Cooper conceded that Bradley had "done much better in the genre," she thought it was her own prose "Croquis" that had achieved "art and expression" in the "flashes of nature round a human drama". ${ }^{3}$ Perhaps here she had in mind the prose work "A Maenad" in which the sensuality of the young female protagonist is in harmony 
with the natural environment. ${ }^{4}$ Cooper goes on to praise various contributors to the volume (including Meynell and Canton) for their ability to capture nature in a "personal way". Regardless of the injustice Cooper does to the poems in Underneath the Bough, many of which were written in the aftermath of Cooper's mother's death and offer a deeply "personal" reflection on the relationship between mortality and nature, she and Bradley clearly aimed to do better. Yet, as I will argue in this essay, they didn't wholly agree with Rinder that Wordsworth offered them a model for writing nature poetry. Rather, they saw Wordsworth as an obstacle to writing nature with the truly Bacchic intensity that they craved. In "Works and Days" and poems in the latter half of the 1890 s we see them attempting to forge a new nature writing aesthetic that rejects what they saw as the overt moralising of Wordsworth's poetic and its tendency to circumscribe the sensuality of the natural world. In particular, I want to argue that the extraordinary cluster of floral poems produced in the summer of 1894 , all of which were added to the American edition of Underneath the Bough, published by T. B. Mosher in 1898, reveal their radical attempt to eroticise nature, instigated by a hitherto neglected episode in their life when they spent Easter of 1894 in Berkshire, worshiping daffodils.

\section{Wordsworth, Decadence, Influence}

Michael Field had, like so many Decadents and aesthetes, a complicated relationship with the Romantic poets. It is impossible to generalise about how writers from these movements responded to the Romantics, for each Decadent and Aesthete had their own affinities with and aversions to their Romantic forebears. Take Wilde, for instance: Keats was a youthful idol and a perennial favourite; Chatterton was of vital importance in developing his Decadent idea of authorship; Wordsworth he mocked mercilessly, noting that the poet of the Lakes "not infrequently wrote like the Distributor of Stamps." Arthur Symons, in his expansive study The Romantic Movement in English Poetry (1909), argued that, despite their heterogeneity, the poets of 
English Romanticism (and his view of them was intensely nationalistic) ushered in a step-change in English letters: "What all these poets, so different in inspiration and tendency, united in was in an aim at the emancipation of the world and of the mind and of the vehicle of poetry from the bondage, of fact, opinion, formality, and tradition; and when fact, opinion, formality, and tradition go out, imagination comes in." ${ }^{\prime 6}$ For Symons, the Romantics had broken with the formal straitjacket and the social conformism of the eighteenth century, which he considered to be an anomaly in the history of English literature. In his characterisation of the Romantics we can hear echoes of some of the formulations in his influential 1893 essay "The Decadent Movement in Literature". Yet for Symons not all Romantics were equal. Blake was a true visionary, Coleridge possessed great intellectual energy. Yet, of Wordsworth, Symons had very little positive to say. It was his poetic naïveté that made him, for Symons, such an inconsistent, and quite often banal, poet. Wordsworth's lack of judgement meant that "he would listen to no external criticism, and there was no inherent critical faculty to stand at his mind's elbow and remind him when he was prophesying in the divine language and when he was babbling like the village idiot" (Symons, p. 80). Of Wordsworth's much vaunted attempt to capture the natural rhythms of speech and the freshness of innocence, Symons was aggressively disparaging: "Wordsworth had a quality of mind which was akin to the child's fresh and wondering apprehension of things. But he was not content with using this faculty like a man; it dragged him into the depths of a second childhood hardly to be distinguished from literal imbecility" (Symons, p. 87). As tin-eared as Symons may be here, his comment captures something of his perception that Wordsworth failed as a poet because of his inability to refine and restrain his imagination, to distil into his poetry an aesthetic impression. Other Decadent writers would find in Wordsworth a bracing alternative to the sybaritic French tradition. George Moore in his creative autobiography Confessions of a Young Man (1888) would declare that even though he was "feminine, morbid, perverse," he saw Wordsworth as "the only simple-minded man I ever loved, if that great austere mind, chill even as the Cumberland year, can be called simple." 
Yet the enthusiasm of Moore and the hostility of Symons and Wilde to Wordsworth is only part of the story. The relationship between Romanticism and Decadence was, for many years, understood through the paradigm of influence, most famously outlined by Harold Bloom in The Anxiety of Influence (1973). It was also common to see the Decadents of the fin de siècle as inheriting, and exhausting, the philosophical and literary forms of the Romantic generation, an influential thesis put forward by Graham Hough in The Last Romantics (1949). Yet these paradigms rely, as Talia Schaffer and Kathy Alexis Psomiades have argued, on a limited and limiting set of assumptions, namely that it is a "primarily masculine trajectory" which frames aestheticism as the "late and somewhat enfeebled version of a Romanticism that had its vigorous beginnings in William Wordsworth," becoming "ever more exhausted" in Swinburne and Rossetti, before fading out with the Decadents and then being transformed into the hard sculptural poetic of modernism by W.B. Yeats, T. S. Eliot and Ezra Pound. ${ }^{8}$

Recent years have seen a number of works revisiting the place of Decadence within the history of English literature, and in particular interrogating the influence model that dominated earlier accounts of its relationship with Romanticism. As the essays gathered together in Kostas Boyiopolous's and Mark Sandy's Decadent Romanticism: 1780-1914 (2016) make clear, the impact of Romanticism on Decadence, and the ways in which Romanticism contains within it the germinating seeds of the Decadent aesthetic, require a more sensitive and dialogic method of reading. As Sandy and Boyiopolous note "Decadent and Romantic sensibilities are in constant negotiation, dialogue, overlap, negation, continuation, transmutation." Perhaps the most important recent development in our critical understanding of the relationship between Romanticism and Decadence has come via Vincent Sherry's claim in Modernism and the Reinvention of Decadence (2014) that the Decadent sensibility is shaped by that realisation, disappointing as it always is, of one's living belatedly in a period in which the possibility for radical change has all but evaporated. The Decadents share, he argues, with Thomas De Quincey a sense that they can no longer have access to the Wordsworthian "spot of time," that moment of imaginative vision 
and unlimited potentiality. As Sherry puts it "It is the disturbance of ideal time. That grand romantic adagio of harmonized and reconciled times, which holds the moments of childhood and adulthood in a single continuum of imaginatively coherent feeling, has decayed."10 That sense of belatedness, of feeling dislocated from, but artistically circumscribed by, the Romantics was one that emerged in contradistinction to the broader late-Victorian celebration of the mostloved of these poets, William Wordsworth.

Though Stephen Gill's Wordsworth and the Victorians (1998) offers an influential account of the poet's afterlife, his narrative makes very little of Walter Pater's idiosyncratic interpretation of the poet's work, and practically nothing of the way that poets of the 1890s, and most particularly women, responded, in Pater's wake, to Wordsworth's philosophical poetic. In Gill's narrative, the 1880s and 1890s saw a renaissance and consolidation of Wordsworth's reputation, with the establishment of the Wordsworth Society in 1880, and the role the poet's vision of the Lake District played in the campaign to challenge the laying of a railway line through the landscape, a campaign that would be influential in the foundation of the National Trust in 1895, all symptomatic of Wordsworth's growing respectability following earlier attacks on him by conservative evangelicals. In the poetic world, Gill identifies such reverent tributes as William Watson's long 1890 elegy Wordsworth's Grave as indicative of the influence Wordsworth had on late Victorian literature. ${ }^{11}$ In many ways Gill's account of Wordsworth at the fin de siècle is about the great Romantic becoming unyoked from radical aestheticism, in particular Pater, for, "since Swinburne's Poems and Ballads (1866) a suspiciously French contagion had been around and what Pater did was to contaminate Wordsworth with it" (214). Yet the Wordsworth of the 1890s was not merely accepted as a conservative poet of nature, and the associations with radical aestheticism were not so easy to shake off. Particularly for women writers of the period, Wordsworth was both an inspiration and a constraint. Linda K. Hughes has traced in Amy Levy's poetry an intertextual dialogue with Wordsworth, in which "Levy ironizes Wordsworth, repurposing his benign optimism and faith in nature into the darker tones of depression and 
loss". ${ }^{12}$ In 1923 Alfred Noyes had claimed that Alice Meynell's work was closer to Wordsworth's than that of any other poet, for "in intellectual and spiritual nature she towers above the deniers of the hour". It was specifically in "her knowledge and love of nature; in the power with which she can suggest its tidal movements, or make a poem open like a window upon the colours of an evening sky" that the comparison with Wordsworth was strongest. ${ }^{13}$ In "A Northern Fancy" Meynell wrote that "the world has become once again as it was in the mad maid's heyday, less serious and more sad than Wordsworth; but it has not recovered, and perhaps will never recover, that sweetness. ${ }^{14}$ Emblematic of that loss of sweetness was the disconnection from the natural world in modernity. Where Huysmans would famously revel in the hothouse of artifice in $\dot{A}$ rebours (1884), Meynell in "The Daffodil" attacks a culture that has lost all connection with nature, in which "the golden name of daffodil has lost its vernal sound". ${ }^{15}$ As Sharon Smulders has argued though, Meynell's relationship with Romantic poetry was far from uncritical, and she challenged the limited and limiting Romantic images of femininity, to develop a model of literary history and poetic practice that could see "past Wordsworth and the rest," as Meynell put it. ${ }^{16}$ Levy and Meynell had then successfully renovated and repurposed Wordsworth's aesthetic for the fin de siècle, yet for other female aesthetes his poetic treatment of the natural world was limited and limiting. Whether it be the moralising vision of nature, or the passive personification of flowers as female, Wordsworth's ecological poetic was inherently gendered and lacking in erotic vitality.

We can place Michael Field alongside Levy and Meynell as female aesthetes who developed a critical intertextual dialogue with Wordsworth at the fin de siècle. Yet as Martha Vicinus has argued, Michael Field shared very different understandings of poetic practice: Bradley "balanced the feminine, irrational roots of creativity — its Bacchic elements—with her masculine claims to literary genius", while "Cooper, in contrast, looked back to the Romantics; she believed that feeling, rather than knowledge, was the source of her lyric inspiration". ${ }^{17}$ This characterisation of the split between Cooper and Bradley does a disservice to Cooper who was 
widely read and whose talent as one of the great prose writers of the fin de siècle has yet to be appreciated. Both women, Catherine Maxwell notes, were "fervent admirers" of both Shelley and Keats, and had been members of the Shelley Society in the late 1880s and early 1890s, and drew with some regularity on Shelleyean motifs. ${ }^{18}$ It could be assumed that Wordsworth's poetry, with its high moral tone, valorisation of innocence, and celebration of Nature, was antithetical to Decadent poetics and politics. Michael Field themselves seemingly subscribed to the narrative that places Wordsworth at the opposite end of the literary spectrum from Decadence. They famously took a high moral line against the Yellow Book when it first arrived in bookstores in 1894. They declared it "full of cleverness such as one expects to find in those who dwell below light $\&$ hope $\&$ love $\&$ aspiration. ... Education Sentimentale by Beardsley $\&$ his bookplate are nightmares from exotic house of ill-fame. One must go to one's Wordsworth \& Shelley to be fumigated." ${ }^{19}$ Bradley's admiration also extended to Dorothy Wordsworth, declaring in 1886 that she was "the only English woman I rank as a poet". ${ }^{20}$ These statements needs to be taken with some caution, as the two women were accustomed to taking exaggerated positions on a writer or artist, only to take a radically different one sometime later. As Treby notes, Bradley could declare that "almost all Shelley is within the enchanted pale. Masses of Wordsworth are for tillage", but then later Cooper explains that for Bradley "Wordsworth can sweep before one all the pageantry of the soul" (Treby, p. 45). Given such inconsistencies, their contemporaries were liable to be confused by the role Wordsworth played in their poetic imagination. In his essay on Michael Field for the ninth volume of Alfred H. Miles's The Poets and the Poetry of the Nineteenth Century, dedicated to women poets, Lionel Johnson suggested that "she" had something of Wordsworth's tragic quality. Wordsworth, for whom "secluded and simple country lives can yet be tragic" was, for Johnson, echoed in Michael Field's verse dramas such as Brutus Ultor (1886) and Canute the Great (1887):

That which a man of science, some master of the comparative method in history or in anthropology, would term a tendency, is for Michael Field a tragic motive: and thus she 
acts well upon that lofty definition of poetry, that it is "the impassioned expression, which is the countenance of all science," and also "the breath and finer spirit of all knowledge." And this very power of hers gives to her a fine simplicity of purpose and of construction. $^{21}$

Johnson's account of Wordsworth's influence eschews the centrality of "nature" writing and the pastoral tradition to the work of Bradley and Cooper. Johnson tried to make the poetry of Michael Field elevated and cerebral, when, as I claim, their response to Wordsworth was to jettison the cerebral in favour of the sensual. Johnson had made the comparison - this time unfavourable - with Wordsworth in an earlier review of The Tragic Mary in which he claimed that Michael Field's plays suffered from a lack of precision in language, from an exuberance of expression. Comparing their depiction of Mary to Wordsworth's sonnet on Mary's captivity, he notes: "we see the difference between an extravagant and a moderate use of language". ${ }^{22}$ Michael Field's extravagant use of language was one means by which they self-consciously set themselves apart from Wordsworth.

The challenge to Wordsworth that emerges in Michael Field's poetry and "Works and Days" is, I want to suggest, not just a challenge to the philosophy that underpins his poetic, but also part of a dialogue with - arguably - two of the most important influences on them who had both written about Wordsworth: Walter Pater and John Ruskin. Pater's essay on Wordsworth (1874) is a typically masterful exercise in ambiguity. Divining a clear argumentative line in it is difficult, yet perhaps the dominant concept underpinning it is what he terms "impassioned contemplation". The term passion appears repeatedly in the essay as Pater attempts to articulate something like a spiritual vitality in Wordsworth's poetry. The importance of passion can be seen in Wordsworth's tendency “to depict people from humble life, because, being nearer to nature than others, they are on the whole more impassioned, certainly more direct in their expression of passion, than other men: it is for this direct expression of passion, that he values their humble words." ${ }^{23}$ How does the passion Pater elevates here relate to that homoerotic passion he 
celebrates so lyrically in Studies in the History of the Renaissance (1873)? When we reflect that, at one point, the Wordsworth essay was to be included in The Renaissance, perhaps we should be reading Wordsworth as the inheritor of Winckelmann's Hellenic spirit? Yet as Michael Field would demonstrate, passion in Wordsworth was contemplative and solipsistic, treating the external world as a source of inspiration for philosophical reflection rather than of queer rapture.

Michael Field's Wordsworth is then something of a correction to Pater, but also a return, in part, to Ruskin's appraisal of the Lake Poet. In the third volume of Modern Painters (1856) Ruskin reflected that Wordsworth's vision of the natural world was both too cerebral and too egotistical: he "cannot altogether rid himself of the sense that he is a philosopher, and ought always to be saying something wise. He has also a vague notion that Nature would not be able to get on well without Wordsworth; and finds a considerable part of his pleasure in looking at himself as well as at her." ${ }^{24}$ Ruskin's criticism here, reflecting his mature circumspection following earlier enthusiasm for The Excursion in particular, ${ }^{25}$ was echoed by Michael Field, both in their discussion of Wordsworth in "Works and Days", and in their attempts to transform their own nature poetry. They realised that pleasure was not to be found by objectifying nature, but by giving one's self up to the fecund vitality of the natural world. Yet aspects of Ruskin's treatment of Wordsworth were likely less amenable, such as his enthusiasm in Sesames and Lilies (1865) for the poet's description, "in a few syllables," of "the completion of womanly beauty."26

Wordsworth's celebration in the "Lucy" poems such as "Three Years She Grew in Sun and Shower" of those "vital feelings of delight" that "Shall rear her form to stately height, -/ Her virgin bosom swell," might have seemed noble to Ruskin, but would be for Bradley and Cooper a problematic attempt to circumscribe the queer vitalism of the natural world. ${ }^{27}$

Cooper's sense, on receiving Rinder's anthology, that their nature writing had been "too stiff" and lacking in "emotion" and "personal" feeling is borne out in the nature writing (of sorts) that was to be found in Long Ago, Sight and Song and the first edition of Underneath the Bough. While there were notable exceptions, such as "The Sleeping Venus," too often in these 
collections figures were placed in nature rather than the natural environment being in a symbiotic relation with the human figure or the speaker. The anxiety over how to write nature can be mapped on to the aesthetic philosophy that they had developed over the course of their writing career, particularly the division they maintained between the "intellectual" and the "emotional". As Cooper would put it in Works and Days, in a manner that echoes Bernard Berenson's and Vernon Lee's exercises in psychological aesthetics, beauty is "that in the objective world that attracts emotion"; art is "the reissue of an emotion of beauty into the objective world as an object". ${ }^{28}$ In their best nature writing they manage to fuse the emotional with the immediacy of the personal experience of nature. In doing so they saw themselves as challenging the tradition of English nature writing which, arguably, in the wake of Wordsworth was tied too much to the philosophical contemplation of the natural, rather than the sensuous immediacy of experience. The transition from the philosophic to the sensual has its roots in a holiday they took in 1894, an episode that has hitherto been neglected by Field scholars.

\section{In the Daffodil Fields of Hermitage}

In March of 1894 Bradley and Cooper travelled to the village of Hermitage in Berkshire where they stayed at The Fir Trees Inn. The motivation for choosing this particular place is unclear - the countryside around Hermitage is lacking the dramatic scenery, the literary heritage, or the proximity to close friends that was their usual motivation for domestic travel. ${ }^{29}$ Cooper wrote that their journey from London via Reading was "of the homogenous kind - no break, no adventure," yet the two women were, at the height of their Bacchic phase, able to make the homogenous extraordinary: the woman who ran the lodging house in which they were staying lit a fir-cone fire which becomes "a most Bacchic sight". The next morning the two women went out walking and came across their first daffodils. Their treatment of daffodils in Works and Days and in their letters are demonstrative of their aestheticist rather than Romantic understanding of 
nature. A daffodil is not to be the object for intellectual meditation, rather the vehicle both literary and religion resonance, as well as sensual experience.

In a letter to Alice Trusted, Cooper describes the impression the daffodils made upon them:

Yesterday we saw our first daffodils: they were growing in awful peace. The sun was setting: it had reached the tranquil, not the coloured stage; the air held more of its effect than the sky yet showed. We did not pluck a daffodil: they grew inviolable. After sunset, as we came thro' the firs, we saw a round glow behind them it was the Paschal moon rising. A chafer passed, like the twang of one string of an Æolian harp. The sound of the wind in the firs is cosmic, the gathering of many waters etherealized; and the sharp notes of individual birds cross it with their smallness, and with a pertinacity that can throw continuance itself into the background. ${ }^{30}$

The inviolability of the daffodils, their sacred presence, was to be a recurring note in the journal entries from that holiday. Yet the daffodils become a symbol simultaneously Christian and pagan. Bradley writes "the daffodil is a flower that 'appears not unto men to fast' - but when one sees it in its own little cluster of blue leaves, with its bent abstracted head, one feels it prays." ${ }^{31}$ Bradley here is quoting from Matthew 6:18, in which one who fasts secretly will be seen by God and rewarded openly. The daffodil then seems to be symbolise a riot of spring colour it looks to be a pagan symbol - yet with care one can see that it is indeed reverent and Christian. Cooper, by contrast, reported this first encounter with daffodils very differently; the tranquillity of the flowers was likened to "the eyelids of the little work woman in the morgue." ${ }^{2}$ The still, silence of the inviolable daffodils generates contemplation and reflection in the two women; following a moonlit walk under the pine trees, Cooper writes "We are happy at present - the

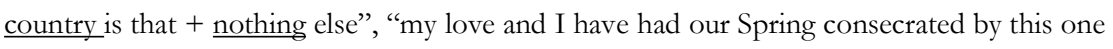
day." 33 The consecration was both Christian and Pagan; the two women lay on a bank in the sun 
talking of Fauns and Bacchus, cutting a hazel wood for a thyrsus, while reflecting on the religious qualities of daffodils:

What can be lovelier than daffodils with plenty of space round each flower, the gold of the sun on the deep and pale gold of each; shadow moving on the perianth, shadow working under the fringes of the corona. Daffodils seem to be solitary by election; they respond to the breeze as if they savoured it (comme ils le savaient [as if they knew it]). And they too light up from the earth, as if they felt its stimulus immediately - they are so fine, so chastened and withal so quiet that they are votaries of the most exquisite pleasure, when the sun shines and the wind stirs. Coming on them is like coming on Dion's companions. ${ }^{34}$

The daffodils are, importantly, solitary. Cooper and Bradley will rarely describe natural phenomena as a collective mass, and it is particularly striking in the case of daffodils which always appear in large numbers. Rather they individualise each flower; the description here is precise and restrained. The characteristics of the daffodils - chaste and silent - suggest that the flowers have all the qualities of the cloister. Yet this all-female community of solitude is chaste and silent so as to better worship the exquisite pleasures of nature, rather than to deny them. For both women, Cooper in particular, Christian faith was not to be characterised by repression, but rather by the elevation of sensual experience. As they found visiting Hermitage, the value of Christian symbolism was its symbiosis with nature:

What infinite magic there is in the word resurrect - it is the abstract synonym of Spring; the Christian legend fits in so exquisitely with March and April - the solemn bitterness of death on Good Friday - on Saturday the austere quiet before life leaps out, the seals that withhold it - the East winds and frosts that watch against its rising and then on Sunday the appearance of the pure force of life before anyone is awake - and afterwards it is joy everywhere. ${ }^{35}$ 
The cycle of Holy Week, giving way on Easter Sunday to Eastertide then seems to fit perfectly with the rhythms and cycles of the natural world. Yet importantly the religious frameworks here are never moral, only ever a means - a formula - for making sense of natural phenomena. On Easter Sunday the two women returned to the copse now filled with daffodils, reflecting on "each enjoying its breath of life." As they gaze on the daffodils their thoughts turn to Wordsworth. Their reverence for the daffodil could not be more different from Wordsworth's famous "I wandered lonely as a Cloud" in which the value of a "Host of dancing daffodils" is found when "They flash upon that inward eye" that "then my heart with pleasure fills, / And dances with the daffodils" (Wordsworth, pp. 303-4), Their treatment of the daffodils is reverent, treating the flower not as a symbol of, or occasion for, imaginative reflection, but as betokening the much more universal condition of resurrection and rebirth.

Cooper and Bradley would read Wordsworth "every now and then", but the daffodils sent them back to the great Romantic, and in particular to "Ode on the Intimations of Immortality". They were both drawn to his poetry yet found it oddly lacking: "we find in his verse the sounds, the functions, the very forms we have left in the world of the daffodils. Nature has betrayed herself to him - one is afraid to listen as he repeats the confidence. And yet how earth to earth he is when he philosophises - as the Doctrine [Bernhard Berenson] would say his 'thinker' has none of the artist in its composition - nothing!"36 The limitations of Wordsworth stem not from his reflection of what he finds in the natural world, but from the intellectual frame he imposes on it. In this Michael Field seemingly concur with Wilde who claimed in "The Decay of Lying" that Wordsworth "found in stones the sermons he had already hidden there." ${ }^{37}$ It was a specific "sermon" though that Bradley and Cooper found distasteful in Wordsworth, the Anglican Burial of the Dead, the focus on mortality, and on nature as an intimation of human death. Wordsworth famously concluded his poem "the meanest flower that blows can give / Thoughts that do often lie too deep for tears" (Wordsworth, pp. 297-302.). As Scott Hess notes, one of the reasons that these thoughts lie too deep for tears is because the poet "no longer 
acknowledges a physical body with which to cry. ${ }^{\prime 38}$ Affective, embodied, emotional experience in the world must be denied in order for philosophical reflection to emerge. It is an approach that both women will increasingly reject in their poetry from this point.

On Easter Monday Bradley and Cooper left Hermitage for Newbury, but not before they had said goodbye to their daffodils. Cooper writes "that these quiet flowers alone have open ears, sensible to every bit of poetry that moves over them through the air. They are an audience." Whereas daffodils spoke to Wordsworth and betrayed their secrets, for Michael Field flowers became an erotic partner to whom they would pour out their devotion. Where Wordsworth would use the daffodils as a spur to introspection, Michael Field watch and learn: "we watch them with their backs mostly to us as they face the sunset and the mellow radiance drenches them through and through. We have learnt every lovely habit, every intimate loveliness of their brief spring." 39 Their short sojourn in Hermitage was to be a source of creative inspiration for many years. While there Bradley penned "Wind through Fir Trees" on Easter Even, prefaced by a quote from Othello ("Methinks the wind hath spoke aloud") and addressed to the wind who is like "a god who has lost his memory / In search of the things that were wont to be." ${ }^{40}$ Bradley would return - spiritually and poetically - to the daffodil fields of Hermitage some years later when, in 1902, she penned "White Madness" in which "a gold daffodil grows white and dumb, / Trembling a little". "Where winds abound" was also inspired by their time at Hermitage and offers a graceful rejection of any account of nature that will attempt to philosophise rather than revel in simple joy:

Where winds abound,

And fields are hilly,

Shy daffadilly

Looks down on the ground.

Rose cones of larch 
Are just beginning;

Though oaks are spinning

No oak-leaves in March.

Spring's at the core.

The boughs are sappy:

Good to be happy

So long, long before! (20).

It was, indeed, good to be happy, and happiness comes from being in harmony with the natural world.

On returning to Reigate the two women would that summer write some of their most strikingly sensual lyrics. Wordsworth may have entombed the daffodil in his "inward eye", but Bradley would pen a series of floral and nature poems in which touch, smell, and sight come together in an immersive, erotic lyricism. There is no intimation of death here, or even of philosophical contemplation, rather fecund desire. Recently the critical reception of Michael Field's work has come to note these earthy, vegetal qualities. In their poetry and in particular their diaries, the Fields luxuriate in the queer fecundity of the natural world. As Patricia Murphy notes, Michael Field "forcefully countered the deleterious supposition" that the equation of women with nature was fundamentally passive "by foregrounding the agential component that is decidedly intrinsic to and inseparable from the nonhuman world." ${ }^{\text {42 }}$ Murphy traces what she dubs the "erotic agency" of the botanic world in the poetry of Michael Field, highlighting how the "sexualization of plant life, especially flowers" becomes "more intensive" in the floral poems of Underneath the Bough (111). In her remarkable essay on Michael Field's "vegetable love," Kate Thomas has made a compelling case for Michael Field's "queer ecology." Examining just some of the many erotic plants in the poets' oeuvre, Thomas makes clear that Cooper and Bradley see 
the non-human world not as a series of objects to be memorialised in verse, but rather as participating in a dynamic, generative, symbiotic relationship with their own poetic world. As she concludes, "Michael Field's poetic perspective is made from within the straining seed pod or the trembling calyx of the flower. It is a way of figuring queer capacities and futurities. Thinking from alongside and inside the plant is a way of producing a queer and lush 'evermore."43 Thomas argues that the Fields' nature poetry is inspired by, and is critical of, the model of Christina Rossetti, but I think we can also see in the poems that Bradley wrote in summer 1894 that the queer and lush qualities of their verse emerge as a response to Wordsworth.

\section{Rewriting Underneath the Bough}

Underneath the Bough was, for Bradley and Cooper, the collection of poetry that gave them the most trouble. The book has a complicated publication history: the first edition was published in the spring of 1893, before - as a response to criticism - a new "revised and decreased" edition was published in October. Then, in 1898 a further revised and expanded American edition was published by Thomas B. Mosher, much closer to the first edition, but with 31 additional poems. In the narrative of this tortured process of remodelling, we can see subtle shifts in the ways the Fields saw themselves as writers of the natural world. The period between the publication of the "pruned" second volume (October 1893) and the extended American volume of 1898 was one of great personal and professional anguish for the Fields. It saw: their relationship with the Berensons become increasingly fractious before it blew up completely in 1895; the public humiliation of the disastrous performance of their play A Question of Memory on 27 October 1893; the death of their dear friend and supporter, the critic John Miller Gray on 22 March 1894; the increasing influence of Charles Ricketts and Charles Shannon, whom they had first met in early

1894. This was a period in which many of the beliefs and convictions they had developed in their "aesthetic" phase were shaken, and a more sensuous, less restrained poetry emerged. 
To understand the changes between the second and third editions, it is necessary to explain a little of the development and reception of Underneath the Bough. The collection's title is taken from Edward FitzGerald's translation of the Rubáiyát of Omar Khayyám (1859), the following lines from which appear as an epigraph to the book:

A Book of Verses underneath the Bough,

A Jug of Wine, A Loaf of Bread—and Thou

Beside me singing in the Wilderness-

Oh, Wilderness were Paradise enow!

This epigraph works to foreground the sensual pastoral qualities that Michael Field were trying to capture, and of the Bacchic note they were endeavouring to strike. The other clear influence, as Joseph Bristow has argued, is Elizabethan poetry, with the structure of the first 1893 edition emulating the songbooks of Thomas Campion which had recently been collected and published by A. H. Bullen (1889). ${ }^{44}$ In wearing these two influences so openly, Cooper and Bradley were seemingly eschewing their debt to Romantic writers who may have been expected to be models for nature writing.

The first edition received a glowing review from John Miller Gray who commended the influence of Bacchic pantheism on the volume:

if its final poem ends the book with a burst of lyric appeal to Bacchus for his inspiration, we may be sure that it is the rightly divine Bacchus who is here invoked; and that the wine prayed for is nought but that draught of strong poetic vintage that shall clarify and not dim the eyes, that shall make them keen to divine the shows of the world, and to pierce into the ether of the imaginative existence which girds it, and begins where the rim of our mortal world ends.

As Gray notes there is in these poems an embrace of a pantheistic worldview which sees death as marking not the end of a life but the process of perpetual creation, of which their poetic vision seeks to be a part. Yet Gray also intimates that there is an otherworldly "absence of 
passion" from these poems, or more specifically "the substitution for passion of something intenser still". ${ }^{45}$ Augusta Webster's review in the Athencum was equally positive, declaring: "The two great thoughts, Death and Love-with Sorrow for the inner name of both—are in fact almost the sole inspirations of the whole, but there is no monotony." Webster was adamant that despite the collection's attempt to echo the style of the Elizabethans, it was far from being nostalgic or backward looking: "A peculiarity of these poems is that while they are of antique mould, ancestral not merely in form but in expression, they are in feeling distinctively modern." ${ }^{46}$ Yet despite these endorsements from critics they admired, Cooper and Bradley were fundamentally dissatisfied with the work. Bristow explains that Bernhard Berenson and Mary Costelloe had been critical of the volume, in particular what they perceived to be its antiquated, anachronistic, Elizabethan air. Encouraged by Berenson's imperative to "be contemporaneous" they produced a revised and shortened edition for publication in November 1893, stripping out the song-book structure along with a number of poems (Bristow, p. 57). Marion Thain offers a more conceptual account of the transformation between the editions. In her reading the first edition interweaves hetero- and homoerotic poems into a "synchronic" form, while the second edition creates a "diachronic" temporal movement, progressing "from uncertainty, to a normative heterosexual phase, and then on in to a celebratory homoerotic landscape" ${ }^{47}$ For Robert P. Fletcher the first edition too was characterised by an aesthetic of incompleteness, whereby readers were encouraged to segment and rearrange the volume into ever queerer narratives. $^{48}$

Michael Field's attempt to refine and modernise the volume in the second edition was not universally appreciated by critics, either at the time or in later scholarship, and the two women themselves quickly came to see the second edition as a pale mutilation. Richard Le Gallienne, in typically spiteful form, declared in his review in the Pall Mall Gazette that the reduction of length had not gone far enough: "The bough might have been improved by severer pruning, which, however, would perhaps have had the effect of "decreasing" it to the 
dimensions of a sprig”. Le Gallienne's quibbles were many, such as his dismay at their rendering of "nimbler" as a tri-syllabic word and "the employment of grotesquely inappropriate word and phrases for the rhyme's sake". He concluded by declaring that "'Michael Field' has shown more courage than either taste or dexterity - to say nothing of discretion," before - the cruellest cut of all - lavishing praise on the binding and typography. ${ }^{49}$ The Fields shelved the collection but they were not done with it. Some years later the American publisher of all things Decadent, Thomas B. Mosher of Portland, Maine approached them to see if they might be interested in publishing with him, and they took the opportunity to revise Underneath the Bough. The poems they added to the 1898 Mosher version were largely written in the intervening years and, taken together, mark not a change in approach - as Thomas notes, flowers had been used as a queer symbol of their shared life as early as 1881 when they adopted the bramble-bough as their emblem - but an intensification of the relationship between nature and the erotic (Thomas, p. 27).

Of the 31 poems they added to the 1898 third edition, ${ }^{50}$ it is those written in spring and summer of 1894 that offer a riposte to Wordsworth and see the emergence of a more intensely erotic and material, rather than philosophical, account of the natural world. "Tiger-Lilies", penned by Bradley in June 1894, and first published in The Atlantic Monthly in September 1895, ${ }^{51}$ signals a radical departure from the "stiff" nature poems of the first two volumes of Underneath the Bough:

Lilies, are you come! Commented [AM1]: I have tried as best I can to approximate the odd lineation of the original which can be found here:

I quail before you as your buds upswell;

https://archive.org/details/underneathboughb00fielrich/page/9 It is the miracle

Of fire and sculpture in your brazen urns

That strikes me dumb, -

Fire of midsummer that burns,

And as it passes,

Flinging rich sparkles on its own clear blaze, 
Wreathes with the wreathing tongues and rays,

Great tiger-lilies, of your deep-cleft masses!

It is the wonder

I am laid under

By the firm heaves

And overtumbling edges of your liberal leaves. (Field, p. 90)

These flowers - no longer the solemn, singular daffodils of hermitage but a riotous collective have struck the speaker, leaving them "quailed", trembling in anticipation at the sight of "your buds upswell". The clear sexual connotations of buds as a metaphor for female sexual development, intensified through the adjective upswell which suggests arousal, and the "brazen" quality of the urns are all suggestive of female desire. These flowers possess qualities both artificial and natural, seemingly forged in fire by the midsummer sun, sculpted by an artificer who holds the speaker in erotic embrace.

An earlier draft of "Tiger-Lilies" began "No poet must surmise what flowers are like / But watch them in their rising spike on spike". ${ }^{52}$ While this admonishment was removed from subsequent drafts, I want to suggest that the poet to whom they offer these words of censure is Wordsworth, and they have in mind specifically his poem "To the Small Celandine." Wordsworth was guilty, they intimate, of characterisation and personification rather than observation and affective engagement. His poem opens with praise of the modest charms of this buttercup perennial in opposition to more exotic blooms: "Pansies, Lilies, Kingcups, Daisies, / Let them live upon their praises". The apostrophe to the flower is pure pathetic fallacy, with the personification making it clear that the demure celandine's charms are those of an ideal woman: "Modest, yet withal an Elf." Other poets become "wanton Wooers" of grander flowers, but it is the "the thrifty Cottager, / Who stirs little out of doors" who can appreciate the arrival of the celandine: "Spring is coming, Thou art come!" The echoes in Michael Field's poem of Wordsworth's is striking: “are you come!” and “thou art come!” are both syntactically unusual, 
and in both there is the intimation of "come" being used as a synonym for sexual orgasm. Yet the exclamation mark in Michael Field's poem is in lieu of a question mark, whereas in Wordsworth it is a declarative statement. Michael Field are conscious of taking the liberty of speaking for the natural world, whereas Wordsworth celebrates not so much the flower as his own lyric evocation of it, with his poem concluding

Singing at my heart's command,

In the lanes my thoughts pursuing,

I will sing, as doth behove,

Hymns in praise of what I love! (Wordsworth, p. 259)

The relationship between speaker and flower is one of inspiration, of nature as the vehicle for reflection. Michael Field's address to the lilies are framed as a testament to the transformative power of the erotic encounter. Where Wordsworth uses the celandine as inspiration for hymns of praise, the speaker in Field's poem is struck dumb, laid under with wonder. There is an erotic sublime in Michael Field's response to nature that arrests and interrupts lyric creativity.

Michael Field's invocation to observe the natural world rather than to use it as inspiration for poetic reflection is played out in "The Depths of the Grass" where they encourage:

Look, in the early light,

Down to the infinite

Depths at the deep grass-roots;

Where the sun shoots

In golden veins, as looking through

A dear pool one sees it do;

Where campion drifts

Its bladders, iris-brinded, through the rifts

Of rising, falling seed 
That the winds lightly scour —

Down to the matted earth where over

And over again crow's-foot and clover

And pink bindweed

Dimly, steadily flower. (Field, p. 86-7)

Michael Field invite us here to think about grass as itself a complex ecosystem that sustains life. It is important that the poem refuses the pathetic fallacy, or to use the grass as the vehicle for poetic reflection. The grass is just grass, home to the modest aesthetic qualities of rose campion and bindweed. Yet in its infinite depths it offers a reminder that nature is an impenetrable mystery rather than a canvas. This celebration of the humble and ubiquitous monocotyledons is, I want to suggest, a response to Wordsworth's “Ode on Intimations of Immortality from Recollections of Early Childhood," in which the joy of gazing upon grass and flower can never be regained:

Though nothing can bring back the hour

Of splendour in the grass, of glory in the flower;

We will grieve not, rather find

Strength in what remains behind;

In the primal sympathy

Which having been must ever be;

In the soothing thoughts that spring

Out of human suffering;

In the faith that looks through death,

In years that bring the philosophic mind (Wordsworth, p. 302).

The recalled, yet distant splendour in the grass of the past becomes in Field the splendour of the grass in the present, the deep reverence not for what the grass may recall to the memory, the "soothing thoughts" of the "philosophic mind," but rather the wonder of nature in 
and of itself. As Scott Hess argues, "Wordsworth celebrated deep feelings of harmony with nature, yet he tended to express that harmony, as in the 'Immortality' ode, in terms of a detached visual consciousness rather than physical embeddedness and participation in the environment." ${ }^{, 53}$ The abstracted visual recollection of the natural world lacked the sensual vitality which Bradley and Cooper craved from their encounter with environments, whether they be the flowers in their garden at Reigate, or the landscapes across the British Isles and Europe which they wrote about so beautifully.

In July 1894, Bradley penned "Your Rose is Dead", or "The Grand Mogul” as it is also known. The lyric intermingles female eroticism with the cycles of death and decomposition, finding an exquisite pleasure in putrefaction, a sensual delight in decay. As the poem concludes: O sweet, let death prevail Upon you, as your nervous outlines thicken And totter, as your crimsons stale,

I feel fresh rhythms quicken,

Fresh music follows you. Corrupt, grow old,

Drop inwardly to ashes, smother

Your burning spices, and entoil

My senses till you sink a clod of fragrant soil! (Field, p. 86).

In her unparalleled reading, Catherine Maxwell argues that the poem is "about the romantic poetic imagination, or the moment of poetic inspiration as Bradley sees it, something that is strongest and most characteristically itself at the very moment when it is about to die, embracing death or the 'dying fall' as the very nature of lyric itself" (Maxwell, p. 236). As Maxwell notes, the poem can be read as a response to Shelley's analogy in "A Defence of Poetry" between poetry and the rose, whereby poetry is "the perfect and consummate surface and bloom of all things; it is as the odour and the colour of the rose to the texture of the elements which compose it, as the form and splendour of unfaded beauty to the secrets of anatomy and corruption." ${ }^{54}$ Yet given 
that Bradley had Wordsworth on the mind at this time we can also read this poem as an interrogation of the Wordsworthian model of poetic inspiration. In the "Intimation Ode" Wordsworth laments that no matter how "lovely the rose" "yet I know, where'er I go, / That there hath past away a glory from the earth". The beauty of nature is, for Wordsworth, always haunted by the intimation of death and the passing of time. Yet for Field the rose's loveliness is inviolable. Even in death and decay the rose is associated with sensual pleasure, or with freedom. Of a pair with "Your rose is dead" is "This rare south rose that thou didst take", in which the gift of a rose from a lover is rejected. The rose has been sent from "across the snows" and has conjured up for the speaker a sensual world: "it has opened me the wild daybreak / And scented all the wind". The flower transports the speaker to Paestum (a city settled by the Dorians in Italy) and to "inmost Persia". The speaker, however, cannot "wear it for thy sake" for the flower is a reminder that "Beauty has such power / She cannot keep a bond; but doth decree / Love in her affluent presence free" (Field, p. 19). The freedom of beauty encapsulated in the rose is a perennial reminder that the natural world exists in, of, and for itself. The task of the lyric poet is not to recall its splendour in the reflective solitude of the mind, but to sing its beauty, to venerate its fecund potential.

\section{Conclusion}

In September 1895 Bradley and Cooper took one of many journeys to the Scottish Borders. This was a landscape reverberating with literary influence. While the account of the trip in "Works and Days" abound with reference to Scott, Hogg, Burns and the Border Ballads, there is another poetic forebear who haunts the banks of the Yarrow. Wordsworth had made numerous visits to the area and published three well-known poems that charted his shifting relationship to it: "Yarrow Unvisited" (1803), "Yarrow Visited" (1814), "Yarrow Revisited" (1838). Yarrowside produces a very site-specific anxiety of influence. Cooper writes: "Michael by 
Yarrowside sings - how? Michael confounded by predecessors does not know." 55 Yet Bradley did find a way to sing, to find her own voice to celebrate nature not in spite of, but in a critical and creative dialogue with the poets of the past. In their poems of nature Michael Field renovate the Romantic model bequeathed to them by Wordsworth. Philosophical reflection is replaced by erotic immediacy, by desire both for and through the natural world, with flowers, grass, and landscapes throbbing with vital energy.

I would like to thank Catherine Maxwell and Sarah Parker for their helpful feedback on a draft of this essay.

${ }^{1}$ Edith Wingate Rinder, "Introduction," Poems and Lyrics of Nature (London: Walter Scott, 1894), pp. xli.

${ }^{2}$ Rinder goes on to quote from the 1874 essay, stating that "Few better things have been said of

Wordsworth in this aspect than the dictum of Mr Walter Pater in his notable essay on the poet", Rinder, p. xxxix.

${ }^{3}$ Michael Field, "Works and Days," BL Add MS. 46782, fol. 51v (June 1st, 1894). In this and all subsequent transcriptions I have substituted "+" for "and".

${ }^{4}$ Michael Field, “A Maenad,” For That Moment Only, Ms. Eng. Misc. d. 976. Bodleian Library, Oxford. Fols. 15-16.

5 Oscar Wilde, 'Australian Poets', The Complete Works of Oscar Wilde, Volume VII, Journalism Part II, eds. John Stokes and Mark W. Turner (Oxford: Oxford Univ. Press, 2013), 132.

${ }^{6}$ Arthur Symons, The Romantic Movement in English Poetry (New York: Dutton, 1909), p. 18

${ }^{7}$ George Moore, Confessions of a Young Man (London: William Heinemann, 1917), p. 48.

8 Talia Schaffer and Kathy Alexis Psomiades, "Introduction," Women and British Aestheticism, eds. Schaffer and Psomiades (Charlottesville, Univ. of Virginia Press, 1999), p. 7.

${ }^{9}$ Kostas Boyiopoulos and Mark Sandy, "Decadent Romantics, Romantic Decadents," in Decadent

Romanticism: 1780-1914, eds. Boyiopoulos and Sandy (Farnham: Ashgate, 2015), p 4.

${ }_{10}$ Vincent Sherry, Modernism and the Reinvention of Decadence (Cambridge: Cambridge Univ. Press, 2014), p. 42.

${ }^{11}$ Stephen Gill, Wordsworth and the Victorians (Oxford: Oxford Univ. Press, 1998), in particular pp. 206260.

${ }^{12}$ Linda K. Hughes, “"Phantoms of Delight': Amy Levy and Romantic Men,” in Decadent Romanticism:

1780-1914, eds. Kostas Boyiopoulos and Mark Sandy (Farnham: Ashgate, 2015), p. 163.

13 Alfred Noyes, “Alice Meynell," The Bookman (Jan 1923): 191.

${ }^{14}$ Alice Meynell, “A Northern Fancy,” Ceres' Runway (London: Constable \& Co. Ltd. 1909), p. 27.

15 Alice Meynell, “The Daffodil,” Ceres' Runway, p. 64.

${ }_{16}$ Smulders, Sharon. "Looking 'Past Wordsworth and the Rest': Pretexts for Revision in Alice Meynell's 'The Shepherdess'," Victorian Poetry 38, no. 1 (2000): 35-48.

${ }^{17}$ Martha Vicinus, "'Sister Souls': Bernard Berenson and Michael Field (Katherine Bradley and Edith Cooper)," Nineteenth-Century Literature 60, no. 3 (2005): 334.

${ }^{18}$ Catherine Maxwell, Scents and Sensibility: Perfume in Victorian Literary Culture (Oxford: Oxford Univ. Press, 2017), pp. 80-1.

${ }_{19}$ Michael Field, "Works and Days," BL Add MS. 46783, fol. 38v (17 April 1894). Their response to the Yellow Book was, it should be noted, coloured by the fact that Henry Harland rejected one of their prose poems for the second volume.

${ }^{20}$ Ivor C. Treby ed., Binary Star: Leaves from the Journal and Letters of Michael Field 1846-1914. (Bury St Edwards, Suffolk: De Blackland Press, 2006), p. 102.

${ }^{21}$ Lionel Johnson, "Michael Field," in The Poets and the Poetry of the Nineteenth Century, Volume 9, Christina G. Rossetti to Katharine Tynan, Alfred H. Miles, ed. (London; Routledge, 1907), p. 292-3.

22 Lionel Johnson, “The Tragic Mary,” The Academy (Aug 16, 1890): 123-124. 
${ }^{23}$ Walter Pater, "Wordsworth," Appreciations; With an Essay on Style (London: Macmillan, 1889), p. 50. ${ }^{24}$ John Ruskin, Modern Painters, Vol. 3 (London: George Routledge, 1856), p. 296.

${ }^{25}$ Dinah Birch, "Elegiac Voices: Wordsworth, Turner, and Ruskin," Review of English Studies 50, no. 199 (1999): 332-344.

${ }^{26}$ John Ruskin, Sesames and Lilies (New York: T. Y. Crowell \& Co., 1891), p. 118.

${ }_{27}$ William Wordsworth, The Major Works, ed. Stephen Gill (Oxford: Oxford University Press, 2008), p. 155.

${ }^{28}$ Michael Field, "Works and Days,” BL Add MS. 46783, fol. 63r (April, 1895).

${ }^{29}$ For an account of Michael Field as travellers see Alex Murray, "Profane Travellers': Michael Field, Cornwall and Modern Tourism," in Michael Field, Decadent Moderns, eds. Sarah Parker and Ana Parejo Vadillo (Ohio Univ. Press, 2019), pp. 167-187.

${ }^{30}$ Edith Cooper to Alice Trusted, March 1894, as quoted in Mary Sturgeon, Michael Field (London: G. G. Harrap, 1922), p. 43.

31 Michael Field, "Works and Days," BL Add MS. 46782, fol. 16v. (March 21, 1894).

32 Michael Field, "Works and Days," BL Add MS. 46782, fol. 18v (March 21, 1894).

33 Michael Field, "Works and Days," BL Add MS. 46782, fol. 18v (March 21, 1894).

${ }^{34}$ Michael Field, "Works and Days," BL Add MS. 46782, fol. 21v (March 23, 1894).

${ }^{35}$ Michael Field, "Works and Days," BL Add MS. 46782, fol. 23v (March 23, 1894).

${ }^{36}$ Michael Field, "Works and Days," BL Add MS. 46782, fol. 25v (March 24, 1894).

37 Wilde, "The Decay of Lying," The Soul of Man Under Socialism and Selected Critical Prose, ed. Linda Dowling (London: Penguin, 2001), p. 173.

${ }^{38}$ Scott Hess, William Wordsworth and the Ecology of Authorship: The Roots of Environmentalism in NineteenthCentury Culture (Charlottesville, VA: Univ. of Virginia Press, 2012), p. 42.

${ }^{39}$ Michael Field, "Works and Days," BL Add MS. 46782, fol. 28v (March 26, 1894).

${ }^{40}$ Michael Field, "Wind Through Fir Trees," Underneath the Bough: A Book of Verses (Portland, ME:

Thomas B. Mosher, 1898), p. 15. The poem first appears in Michael Field, "Works and Days," BL Add MS. 46782, fol. 24v

${ }^{41}$ Michael Field, "White Madness," Wild Honey from Various Thyme (London: T. Fisher Unwin, 1908), p. 63.

42 Patricia Murphy, Reconceiving Nature: Ecofeminism in Late Victorian Women's Poetry (Columbia: Univ. of Missouri Press, 2019), p. 97

43 Kate Thomas "Vegetable Love: Michael Field's Queer Ecology," in Michael Field: Decadent Moderns, eds. Sarah Parker and Ana Parejo Vadillo (Athens, OH: Ohio Univ. Press, 2019), p. 40.

${ }^{44}$ Joseph Bristow, "Michael Field's Lyrical Aestheticism: Underneath the Bough," in Michael Field and Their World, eds. Margaret D. Stetz and Cheryl A. Wilson (High Wycombe: Rivendale Press, 2007), p. 57.

45 J.M. Gray, "Review," The Academy, July 22, 1893.

46 "Review of Underneath the Bough," Athenaum (September 9, 1893). The Fields identify Webster as the author of this anonymous review in Michael Field's Album of Reviews. University of Oxford, Special Collections, MS. Eng.misc.b.47.

${ }^{47}$ Marion Thain, Michael Field: Poetry, Aestheticism and the Fin de Siècle (Cambridge: Cambridge Univ. Press, 2007), p. 124.

48 Robert P. Fletcher, "II leave a page half-writ': Narrative Discoherence in Michael Field's Underneath the Bough," in Women's Poetry, Late Romantic to Late Victorian: Gender and Genre, 1830-1900, eds. Isobel Armstrong and Virginia Blain (Houndsmill: Palgrave Macmillan, 1999), pp. 164-182.

49 "Underneath the Bough," Pall Mall Gazette 1 December 1893, p. 4. Le Gallienne is identified as the reviewer in Michael Field's Album of Reviews. University of Oxford, Special Collections, MS. Eng.misc.b.47.

50 Those 31 poems are: Book 1: "Sweeping, sighing away"; "Spring!"; "Do you see the poppies coming"; "On the gray dawn-track"; "This rare south-rose that thou didst take". Book 2: "I would not have the wind pass by"; "O Love, bitter, mortal journeying"; "They buried him — ah, I have not thought". Book 3: "Have you seen the olives at set of sun"; "She lies asleep : I watching do not dare"; "O sweet, all sweet, the body as the shyer"; "Mine is the eddying foam and the broken current"; "Sweet of my poet how sweet are the eyes,"; "Though I sing high and chaunt above her"; "Shall there ever be a morn"; "I love her with the seasons, with the winds". Book 5: "She fled from love, her suit was granted"; "Two lovers came; of many a common thing"; "We met"; "A train"; "The tips of the hills rise up, like curled"; "Your rose is dead"; "Look in the early light"; "There is a month between the swath and sheaf"; "A branch of 
wild-rose buds"; Lilies, are you come"; "I hear thine iterating voice inflight"; "Stars at break of day"; "His ship has touched the land: what curses"; "Life was a rose, a rose to me"; "As the young phoenix, duteous to his sire".

${ }^{51}$ Michael Field, “Tiger-Lilies,” The Atlantic Monthly, (September 1895): 370

${ }^{52}$ Michael Field, Uncertain Rain: Sundry Spells of Michael Field, ed. Ivor C. Treby (London: De Blackland

Press, 2002), p. 117.

${ }^{53}$ Scott Hess, "Nature and the Environment," William Wordsworth in Context, ed. Andrew Bennett

(Cambridge Univ. Press, Cambridge, 2015), p. 211.

${ }^{54}$ Percy Bysshe Shelley, "A Defence of Poetry," The Prose Works, Vol II. Ed. Richard Herne Shepherd

(London: Chatto and Windus, 1906), p. 32

55 Michael Field, “Works and Days,” BL Add MS. 46783, fol. 151v (September 1895). 